\title{
PERAN KOMUNIKASI KEPALA DESA DALAM PEMBANGUNAN PENDIDIKAN
}

\author{
Antonius \\ Fakultas Ilmu Sosial dan Ilmu Politik Universitas Kapuas \\ Jln. Y.C. Oevang Oeray Nomor 92 Baning Kota Sintang
}

\begin{abstract}
Abstrak: Peran komunikasi Kepala Desa dalam pembangunan pendidikan yang meliputi sosialisasi pembangunan pendidikan, pembinaan masyarakat dalam pembangunan pendidikan dan koordinasi dan pelaksanaan Pendidikan. Peran komunikasi Kepala Desa telah memberikan hasil yang baik terhadap masyarakat namun dalam implementasinya upaya tersebut tidak sepenuhnya didukung oleh masyarakat. Sosialisasi pembangunan pendidikan dibantu beberapa instansi pemerintah daerah telah mendorong masyarakat untuk sadar bersekolah hal ini terlihat semakin meningkatnya angka anak melanjutkan pendidikan. Selain itu pembinaan masyarakat dalam pembangunan pendidikan terus diintensifkan meskipun terdapat kendala kesulitan tenaga yang membina. Demikian juga dengan terhambatnya membangun koordinasi Pendidikan, dikarenakan sumberdaya manusia masyarakat yang masih rendah. Kehidupan social berkaitan dengan perilaku masyarakat masih berpegang pada budaya lama seperti menganggap bersekolah hanya membuang uang. Namun kondisi geografis yang terdapat di Desa Jaya Mentari juga salah satu penyebab lambannya masyarakat berkembang dalam pendidikan. Jarak tempuh yang cukup jauh membuat masyarakat terhalang menyekolahkan anaknya. Oleh karena itu perlu mengintensifkan kerjasama dengan instansi terkait yang ada hubungan dengan pembangunan pendidikan masyarakat khususnya dalam meningkatkan mutu pendidikan. Dinas Pendidikan dapat melakukan control kegiatan secara rutin untuk mengetahui sejauh mana program pembangunan pendidikan berjalan.
\end{abstract}

Kata Kunci: Peran, Komunikasi, Pendidikan

Komunikasi adalah suatu proses pertukaran pesan verbal maupun non verbal antara pengirim dan penerima penerima pesan untuk mengubah tingkah laku. Dalam pembangunan sangat diperlukan baik komunikasi intern maupun komunikasi ekstren dilingkungan pemimpin dan bawahannya serta masyarakatnya. Kedua komunikasi tersebut sangat berpengaruh terhadap kelancaran, kemudahan, dan kenyamanan dalam melaksanakan tugas. Komunikasi intern merupakan komunikasi antar personel yang ada dalam organisasi harus senantiasa dikembangkan, baik oleh Kepala Desa maupun oleh aparatur desa lainnya. Komunikasi intern yang terbina baik akan memberikan kemudahan dan keringanan dalam melaksanakan pekerjaan desa yang menjadi tugas bersama guna merialisasikan program pembangunan.

Dengan adanya komunikasi, masyarakat dapat memperoleh informasi dan petunjuk yang jelas sehingga tidak menimbulkan keragu-raguan dan kesalah pahaman yang ada sehingga akhirnya akan mempengaruhi efektivitas kerja bawahannya.

Peran komunikasi tidak saja sebagai sarana atau alat bagi Kepala Desa menyampaikan informasi, misalnya tentang suatu kebijakan, tetapi juga sebagai sarana memadukan aktifitas-aktifitas secara terorganisasi dalam mewujudkan kerjasama. Desa Jaya Mentari Kecamatan Tempunak Kabupaten Sintang merupakan salah satu organisasi formal di lingkungan perangkat pemerintah Desa yang memberikan kontribusi yang cukup besar dalam pembangunan bidang pendidikan dengan jumlah penduduk 1045 jiwa masih memiliki tingkat pendidikan jauh dari maju. Program-program kerja yang dirancang oleh Kepala Desa bertujuan untuk mempromosikan dan mengembangkan pembangunan pendidikan melalui peranan komunikasi yang efektif supaya dapat memenuhi peran dan fungsinya sebagai aparat pemerintah desa yang mengabdikan dirinya pada masyarakat. Kurangnya komunikasi yang selama ini di bangun Kepala Desa mengakibatkan lambannya perkembangan Desa di bidang Pendidikan. Sementara masyarakat sangat mendambakan adanya perubahan dengan kepemimpinan pengurus desa saat ini. Keterbatasan sarana gedung, jarak sekolah dari warga menjadi kendala, sebab rumah masyarakat Desa Jaya Mentari tidak semua dekat dengan sekolah. Kepala Desa mempunyai peran penting dalam pengembangan pendidikan di daerah sebagai bentuk peningkatan mutu sumberdaya manusia masyarakat.

Pendidikan adalah hak masyarakat. Dalam Peraturan Pemerintah Republik Indonesia Nomor 6 Tahun 2014 Tentang Desa. Menurut Kohler (2001:123) ada dua model komunikasi dalam rangka meningkatkan kinerja dan mencapai tujuan perkantoran ini. Pertama, komunikasi koordinatif 
yang berfungsi menyatukan bagian-bagian perkantoran. Kedua, komunikasi interaktif, ialah proses pertukaran informasi yang berjalan secara berkesinambungan, pertukaran pendapat dan sikap yang dipakai sebagai dasar penyesuaian di antara sub-sub system dalam perkantoran, maupun antara perkantoran dengan mitra kerja. Frekuensi dan intensitas komunikasi yang dilakukan juga turut mempengaruhi hasil dari suatu proses komunikasi tersebut. Dalam hal komunikasi yang terjadi antar perangkat desa, kompetensi komunikasi yang baik akan mampu memperoleh dan mengembangkan tugas yang diembannya, sehingga tingkat kinerja suatu organisasi menjadi semakin baik.

Sebaliknya, apabila terjadi komunikasi yang buruk akibat tidak terjalinnya hubungan yang baik, sikap yang otoriter atau acuh, perbedaan pendapat atau konflik yang berkepanjangan, dan sebagainya, dapat berdampak pada hasil kerja yang tidak maksimal. Dalam Peraturan Pemerintah tersebut dijelaskan kewenangan Kepala Desa adalah sebagai berikut: (1) Memimpin penyelenggaraan pemerintahan desa berdasarkan kebijakan yang ditetepakan bersama BPD, (2) Mengajukan rancangan peraturan desa, (3) Menetapkan peraturan desa yang telah mendapatkan persetujuan bersama BPD, (4) Menyususun dan mengajukan rancangan perauran desa mengenai APB desa untuk dibahas dan ditetapkan bersama BPD. (5) Membina kehidupan masyarakat desa, (6) Membina perokonomian desa, (7) Mengkoodinasikan pembangunan desa secara partisifatif.

Undang-Undang Republik Indonesia Nomor: 20 Tahun 2003 Tentang Sistem Pendidikan Nasional Pasal 1 ayat 1 menjelaskan bahwa" Pendidikan adalah usaha sadar dan terencana untuk mewujudkan suasana belajar dan proses pembelajaran agar peserta didik secara aktif mengembangkan potensi dirinya untuk memiliki kekuatan spiritual keagamaan, pengendalian diri, kepribadian, kecerdasan, akhlak mulia, serta ketrampilan yang diperlukan dirinya, masyarakat, bangsa dan negara." Pendidikan dapat berjalan dengan baik bila mana adanya kerjasama pemerintah dengan masyarakat, dalam hal ini Kepala Desa sebagai wakil masyarakat desa harus mampu mengkomunikasikan pengembangan pendidikan.

Menurut defenisi Hovland(2004:123)" Komunikasi adalah proses yang memungkinkan seseorang menyampaikan rangsangan untuk mengubah perilaku orang lain". Sedangkan menurut Wilbur Scharmm (1976:123) Mass media and national development: the role of information in developing countries. Stanford university press) dalam kajian tentang komunikasi dalam pembangunan nasional menjelaskan peran komunikasi yaitu: (1) Menyampaikan kepada masyarakat informasi tentang pembangunan, agar mereka memusatkan perhatian pada kebutuhanakan perubahan, kesempatan dan cara mengadakan perubahan, sarana-sarana perubahan, dan membangkitkan aspirasi nasional. (2) Memberikan kesempatan kepada masyarakat untuk mengambil bagian secara aktif dalam proses pembuatan keputusan, memperluas dialog agar melibatkan semua pihak yang akan membuat keputusan mengenai perubahan, member kesempatan kepada para pemimpin masyarakat untuk memimpin dan mendengarkan pendapat rakyat kecil, dan menciptakan arus informasi yang berjalan lancar dari atas kebawah. (3) Mendidik tenaga kerja yang diperlukan pembangunan, mulai orang dewasa hingga anak-anak, sejak baca tulis hingga keterampilan teknis yang mengubah hidup masyarakat.

Salah satu jenis komunikasi yang sangat penting adalah komunikasi interpersonal atau komunikasi yang terjadi secara tatap muka antara beberapa pribadi yang memungkinkan respon verbal maupun nonverbal berlangsung secara langsung. Hal ini sesuai dengan pendapat Effendy (1999:54) yang mengatakan bahwa, "Efektifitas komunikasi antar pribadi itu ialah karena adanya arus balik langsung". Di dalam suatu organisasi khususnya perkantoran, proses komunikasi adalah proses yang pasti dan selalu terjadi. Menurut Mulyadi (1989:234) menyatakan ada dua bentuk Komunikasi yakni: (1) Komunikasi ke bawah yaitu dari pimpinan kepada bawahan. Tiap komunikasi yang mengalir dari pimpinan puncak hingga kebawah mengikuti hirarki adalah komunikasi kebawah. Tipe komunikasi ini memilki konstruksi tugas, rasional, ideologi, informasi, dan balikan. (2) Komunkasi keatas yakni dari bawahan kepada atasan. Dalam hal ini pimpinan mendapatkan informasi yang bersasal dari bawahannya. Komunikasi memiliki peran dalam pelaksanaan pembangunan.

Hedebro (dalam Nasution, 2004:95) mengidentifikasi tiga aspek komunikasi dan pembangunan yang berkaitan dengan tingkat analisanya, yaitu: Pendekatan yang berfokus pada pembangunan suatu bangsa, dan bagaimana media massa dapat menyumbang dalam upaya tersebut. Dari sekian banyak ulasan para ahli mengenai peran komunikasi pembangunan, Nasution, (2004:102) mendaftar 12 peran yang dapat dilakukan komunikasi dalam pembangunan, yakni: Komunikasi dapat menciptakan iklim bagi perubahan dengan membujukkan nilai-nilai, sikap mental, dan bentuk perilaku yang menunjang modernisasi. Komunikasi dapat mengajarkan keterampilan-keterampilan baru, mulai dari bacatulis ke pertanian, hingga ke keberhasilan 
lingkungan, hingga reparasi mobil. Media massa dapat bertindak sebagai pengganda sumber-sumber daya pengetahuan. Media massa dapat mengantarkan pengalaman-pengalaman yang seolah-olah dialami sendiri, sehingga mengurangi biaya psikis dan ekonomis untuk menciptakan kepribadian yang mobile.

Komunikasi dapat meningkatkan aspirasi yang merupakan perangsang untuk bertindak nyata. Komunikasi dapat membantu masyarakat menemukan norma-norma baru dan keharmonisan dari masa transisi Komunikasi dapat membuat orang lebih condong untuk berpartisipasi dalam pembuatan keputusan di tengah kehidupan masyarakat. Komunikasi dapat mengubah struktur kekuasaan pada masyarakat yang bercirikan tradisional, dengan membawa pengetahuan kepada massa. Mereka yang beroleh informasi akan menjadi orang yang berarti, dan para pemimpin tradisional akan tertantang oleh kenyataan bahwa ada orang-orang lain yang juga mempunyai kelebihan dalam hal memiliki informasi. Komunikasi dapat menciptakan rasa kebangsaan sebagai sesuatu yang mengatasi kesetiaan-kesetiaan lokal. Komunikasi dapat membantu mayoritas populasi menyadari pentingnya arti mereka sebagai warga negara, sehingga dapat membantu meningkatkan aktivitas politik Komunikasi memudahkan perencanaan dan implementasi program-program pembangunan yang berkaitan dengan kebutuhan penduduk. Komunikasi dapat membuat pembangunan ekonomi, sosial, dan politik menjadi suatu proses yang berlangsung sendiri. Sedang dalam arti yang sempit, komunikasi pembangunan merupakan segala upaya dan cara, serta teknik penyampaian gagasan, dan keterampilanketerampilan pembangunan yang berasal dari pihak yang memprakarsai pembangunan dan ditujukan kepada masyarakat luas. Kegiatan tersebut bertujuan agar masyarakat yang dituju dapat memahami, menerima, dan berpartisipasi dalam melaksanakan gagasan-gagasan yang disampaikan tadi.

Kedua pengertian tadi merupakan acuan dari konsep komunikasi pembangunan pada umumnya. Sedangkan konsep komunikasi pembangunan khas Indonesia menurut Effendy (2005:92) dapat didefinisikan sebagi berikut: Komunikasi pembangunan adalah proses penyebaran pesan oleh seseorang atau sekelompok orang kepada khalayak guna mengubah sikap, pendapat, dan perilakunya dalam rangka meningkatkan kemajuan lahiriah dan kepuasan batiniah, yang dalam keselarasannya dirasakan secara merata oleh seluruh rakyat". Agar komunikasi pembangunan lebih berhasil mencapai sasarannya, serta dapat menghindarkan kemungkinan efek-efek yang tidak diinginkan.
Kesenjangan efek ditimbulkan oleh kekeliruan caracara komunikasi, hal ini bisa diperkecil bila memakai strategi komunikasi pembangunan yang dirumuskan sedemikian rupa, yang mencakup prinsip-prinsip berikut: Pengunaan pesan yang dirancang secara khusus untuk khalayak yang spesifik. Pendekatan "ceiling effect" yaitu dengan mengkomunikasikan pesan-pesan bagi golongan yang dituju merupakan redudansi (tidak lagi begitu berguna karena sudah dilampaui mereka atau kecil manfaatnya, namun tetap berfaedah bagi golongan khalayak yang hendak dicapai. Penggunaan pendekatan "narrow casting" atau melokalisir penyampaian pesan bagi kepentingan khalayak. Pemanfaatan saluran tradisional, yaitu berbagai bentuk pertunjukkan rakyat yang sejak lama berfungsi sebagai saluran pesan yang akrab dengan masyarakat setempat. Pengenalan para pemimpin opini di kalangan lapisan masyarakat yang berkekurangan, dan meminta bantuan mereka untuk menolong mengkomunikasikan pesan-pesan pembangunan. Mengaktifkan keikutsertaan agen-agen perubahan yang berasal dari kalangan masyarakat sendiri sebagai petugas lembaga pembangunan yang beroperasi di kalangan rekan sejawat mereka sendiri. Diciptakan dan dibina cara-cara atau mekanisme keikutsertaan khalayak (sebagai pelaku-pelaku pembangunan itu sendiri) dalam proses pembangunan, yaitu sejak tahap perencanaan sampai evaluasinya (Nasution, 2004:163).

Menurut Nasution (1985:12)), ada empat strategi komunikasi pembangunan yang telah digunakan selama ini, yaitu: (1). Strategi-strategi yang didasarkan pada media yang dipakai. (2). Strategi-strategi disain instruksional. (3) Strategistrategi partisipatori. (4) Strategi-strategi pemasaran. Masing-masing strategi mencerminkan suatu rangkaian prioritas tertentu mengenai bagaimana menggunakan komunikasi untuk mencapai kebutuhan-kebutuhan pembangunan. Sedangkan menurut Dirdjososisworo(1985:119) menyatakan bahwa sosialisasi merupakan sebuah proses penanaman atau transfer kebiasaan atau nilai dan aturan dari satu generasi lainnya dalam sebuah kelompok atau masyarakat. Sosialisasi kebijakan kepala desa dalam komunikasi berkaitan dengan pendidikan tidak bisa dilakukan secara person petugas tim sosialisasi saja melainkan perlu adanya bantuan dari instansi-instansi lain melalui kerja sama antara unsur masyarakat di Dinas Pendidikan serta pengawas sekolah dengan pihak Kecamatan. Kebutuhan terhadap sarana dan prasarana pendidikan yang memadai juga sebagai salah satu penunjang dalam pelaksanaan tugas karena dalam melakukan sosialisasi tidak bisa dilaksanakan dalam waktu yang singkat tetapi juga membutuhkan cukup waktu serta sosialisasi yang 
harus dilaksanakan secara bertahap dan berkesinambungan.

Menurut Koeswadoyo (1995 :35) bahwa pembinaan merupakan proses yang membawa orang-orang berkomunikasi, perkumpulan, penyesuaian dan koperasi guna menghindari masalah yang semakin fatal terjadi. Sedangkan Menurut Hidayat (1993:26) bahwa pembinaan adalah "Usaha yang di lakukan dengan sadar, berencana, teratr untuk meningkatkan pengetahuan, sikap dan keterampilan subjek didik dengan tindakan-tindakanpengarahan, bimbingan, pengembangan dan pengawasan untuk mencapai tujuan yang diharapkan."Pembinaan merupakan proses yang berkelanjutan dan terus di upayakan terhadap masyarakat yang masih memiliki tingkat pengetahuan sangat rendah. Selanjutnya menurut Soemitro (1993:41) mengemukaan bahwa: "pembinaan adalah suatu kegiatan yang bernilai yaitu dampaknya selalu diharapkan dalam bentuk dan wujud kebaikkan, kemanfaatan dan pertumbuhan serta perkembangannya dari suatu yang dibina". Menurut Kadarno (2001:6) karakteristiknya harus adanya integrasi dan singkronisasi atau adanya keterpaduan, keharmonisan, serta arah yang sama. Pentingnya koordinasi ini agar organisasi dapat menciptakan efektifiitas dan efesiensi. Hal ini berarti bahwa tujuan organisasi dapat tercapai dalam pencapaiannya memanfaatkan semua sumberdaya secara hemat dan ekonomis.

Menurut Ma'moeri (2005:123) terdapat beberapa definisi atau konsepsi tentang koordinasi yang diberikan oleh beberapa ahli sebagai berikut : (1).Kordinasi bersangkut paut dengan penyerasian serta pengaturan tindakan dari sekelompok orang. Kegiatan-kegiatan yang terkoordinasi adalah suatu operasi yang kegiatan dari para pegawai atau personil tampak harmonis, saling terjalin serta terintegrasi kearah suatu sasaran yang sama. (2). Koordinasi secara sederhana dapat ditafsirkan bahwa koorinasi itu adalah bekerja bersama se erat-eratnya dibawah seorang pemimpin, karena itu koordinasi dapat terwujud bila ada kerjasama yang seerat-eratnya dari dua atau lebih pihak dalam mewujudkan sesuatu. Supono (2001:9) menyebutkan koordinasi "pada hakekatnya merupakan upaya memadukan. Menyerasikan dan menyelaraskan berbagai kepentingan dan kegiatan yang saling berkaitan beserta segenap gerak, langkah dan waktunya dalam rangka pencapaian tujaun dan sasaran bersama". Soedjadi(1990:87) menyatakan sebagai pedoman dalam melaksanakan koordinasi, maka ada beberapa prinsip sebagai berikut : (a) Adanya wewenang formal dari koordiantor (b). Adanaya saling menghormati wewenang antar pemimpin unit serta antar manajer yang melakukan kerjasama secara terkoordinasi. (c) Sedini mungkin melakukanya itu sejak dimulainya perencanaan kerja yang memerlukan koordinasi dengan mengajak semua pihak untuk menelaah bersama, serta menyesuaikan pelaksanaan rencana tersebut dengan rencana unitnya masing--masing. (d)Terbuka saling berkomunikasi dalam menyampaikan dan menerima informasi yang berkaitan dengan pelaksanaan rencana termasuk masalah-masalah yang ada untuk ditangani bersama. (e) Dimilikinya alat dan metoda koordinasi agar koordinasi ini efektif. (f).Didukung oleh semua sumber yang ada secara tepat, sehingga koordinasi menjadi lebih efektif. (g). Semua pihak harus berpegang pada fungsi dan wewenang masing-masing kordinator maupun yang dikoordinasikan. (h).Koordinasi harus dimulai sejak awal nulai dari penetapan sasaran, penentuan kebijakan, perencanaan, maupun penjadwalan pelaksanaan. (i). Kordinasi harus ada pada setiap pelaksanaan fungsi manajemen, serta pelaksanaan operasionalnya. (j). Harus telah ditetapkan waktu-waktu yang tepat kegiatan koordinasi secara berkala, yang terus menerus dilakukan dalam proses pencapaian sasaran atau tujuan bersama.(k). Pedoman tatalaksana koordinasi harus dirumuskan secara tertulis sebagai pedoman bagi setiap orang yang berpartisipasi mencapai tujuan yang telah ditetapkan bersama. Koordinasi timbul dan sangat dibutuhkan sebagai konsekuensi adannya upaya untuk mencapai tujuan organisasi secara efektif dan efesien melalui pembagian tugas.

Menurut Suganda (1991:30) koordinasi dalam kegiatan pemerintahan dan pembangunan dapat dibedakan sebagai berikut, "koordinasi Hierarkis dan koordinasi Fungsional". Koordinasi hierarki adalah koordinasi dilakukan oleh seoorang pejabat pimpinan dalam suatu instansi pemerintah terhadap pejabat atau instansi bawahannya. Koordinasi macam ini melekat pada setiap fungsi pimpinan seperti halnya fungsifungsi perencanaan, penggerak, pengorganisasian, dan pengawasan setiap pimpinan berkewajiban untuk mengkoordinasikan kegiatan bawahannya. Koordinasi fungisonal adalah koordinasi yang dilakukan oleh seorang pejabat atau sesuatu instansi terhadap pejabat atau instansi lainnya yang tugasnya saling berkaitan berdasarkan azas fungsionalisasi.

Menurut Suganda (1991:31) dalam koordinasi ini dapat dibedakan yaitu: (a).

Koordinasi Fungsional Horizontal koordinasi ini dilakukan oleh seorang pejabat atau suatu unit/ instansi terhadap pejabat atau unit/insatnsi lain yang setingkat. (b) Koordinasi fungsional Diagonal. Koordinasiinidilakukan oleh seorang pejabat atau suatu instansi terhadap pejabat atau instansi lain 
yang lebih rendah tingkatannya tetap ibu kan bawahannya. (c). Koordinasi fungsional Teritorial. Koordinasi ini dilakukan oleh seorang pejabat atau pimpinan atau suatu instansi terhadap pejabat atau instansi lainnya yang berada dalam suatu wilayah tertentu dimana semua urusan yang ada dalam wilayah tersebut menjadi wewenang atau tanggungjawabnya selaku penguasa. Perencanaan sumberdaya manusia akan dapat dilakukan dengan baik dan benar, jika perencanaannya mengetahui apa dan bagaimana sumberdaya manusia itu.

Menurut Hasibuan (2008:244) bahwa: "Sumberdaya manusia atau man power ditingkat SDM merupakan kemampuan yang dimiliki setiap manusia. Menurut Martoyo (2000:6) bahwa: "sumberdaya manusia sebagai alat mencapai tujuan atau kemampuan memperoleh keuntungan dari kesempatan-kesempatan tertentu atau meloloskan diri dari kesukaran berdasarkan kemampuan manusia". Penentuan mutu ini menurut Heidjrachman (dalamMartoyo, 2000:30) akan menyangkut: "a) rancangan jabatan dan, b) studi terhadap tugas dan kewajiban suatu jabatan untuk menentukan kemampuan karyawan yang diperlukan bagi jabatan tersebut. Adapun fungsi peralatan kantor menurut Gie (2000:256) adalah "a) mempertinggi kemampuana paratur yang mempergunakan alat-alat tersebut, b) memperkecil pengorbanan waktu, tenaga dan biaya, c) mempertinggi kualitas dan kuantitas, hasil kerja, dan d) mempertinggi kelangsungan kesejahteraan kerja". Baik dan buruknya perilaku masyarakat tidak terlepas pada kualitas sumberdaya manusia yang dimilikinya.

Menurut Rusmiadi (1999:123) menyatakan bahwa "perilaku merupakan gambaran karakter manusia yang di tarnsferkan melalui tingkah lakunnya dan berdampak bagi dirinya maupun bagi orang lain disekitarnya." Sumberdaya manusia merupakan sarana manajemen yang sangat menentukan dalam proses pelaksanaan pelayanan oleh karena itu keberadaan SumberDaya Manusia selalu menempatkan urutan yang paling atasdarisaranamanajemen yang lainnyaseperti modal, metode, matrial/sarana dan prasarana, mesin/teknologi, market/target group.

Menurut Gomes (2003:3) “ sumberdaya manusia merupakan bagian dari manajemen umumnya memfokuskan diri dari pada unsur Sumber Daya Manusia yang langsung dirasakan oleh organisasi. Perhatian ini mencakup fungsi manajerial, fungsi oprasional, dan peran serta kedudukan sumberdaya manusia dalam pencapaian tujuan organisasi secara terpadu". Selanjutnya Gomes (2003:26) menjelaskan keberadaan unsur sumberdaya manusia dalam mewujudkan tujuan organisasi adalah sebagai berikut: "Unsur-unsur sumberdaya manusia meliputi kemampuankemampuan, sikap, Nilai-nilai kebutuhan-kebutuhan dan karakteristik karakteristik demografi penduduk". Jadi kinerja dari suatu organisasi dapat berhasil atau tidak berhasil sangat tergantung pada keberadaan sumberdaya manusia.

\section{METODE}

Jenis dalam penelitian ini menggunakan deskriptif dengan pendekatan kualitatif. Sesuai dengan tujuan dari pada penelitian ini adalah untuk menggambarkan Peran Kepala Desa dalam pembangunan Pendidikan di Desa Jaya Mentari Kecamatan Tempunak dengan subjek penelitian dalam penelitian ini adalah: Kepala Cabang Dinas Pendidikan KecamatanTempunak, Kepala Desa dan masyarakat desa. Teknik pengumpulan data yang dilakukan melalui Wawancara, Observasi dan Studi dokumentasi. Alat pengumpilan data sebagai berikut: Pedoman wawancara. Catatan lapangan dan Dokumen. Untuk menganalisis data yang diperoleh, teknik yang dipergunakan penulis adalah teknis analisis data secara kualitatif. Penelitian ini berlokasi di Desa Jaya Mentari Kecamatan Tempunak Kabupaten Sintang. Alasan pemilihan lokasi tersebut karena peran kepala Desa dalam pembangunan Pendidikan belum menunjukan keberhasilan nyata dirasakan oleh masyarakat.

\section{HASIL PENELITIAN DAN PEMBAHASAN}

Dalam penyelenggaraan pembangunan, diperlukan suatu sistem komunikasi efektif dan memilikimakna yang mampu mengarahkan pencapaian tujuan pembangunan. Hal itu perlu sekali dilakukan karena proses pembangunan melibatkan berbagai elemen masyarakat. Karena pembangunan tidak akan berjalan dengan optimal tanpa adanya hubungan sinergis antara pelaku dan obyek pembangunan. Konsep komunikasi pembangunan sangat membuka peluang untuk mendorong komunikasi intensif melalui dialog dengan kelompok-kelompok strategis dalam rangka membangun kemitraan untuk mempengaruhi kebijakan public sebelum diputuskan. Berbagai kelompok yang perlu dilibatkan dalam kemitraan antara lain Perguruan Tinggi, LSM, pers dan berbagai elemen pendukung pembangunan lainnya. Jika ingin komunikasi pembangunan berjalan dengan efektif, maka diperlukan suatu pusat komunikasi yang menjadi rujukan dari pelakupelaku pembangunan maupun pihak-pihak yang berkompeten dalam penyelenggaraan pembangunan untuk memperoleh informasi dan koordinasi pembangunan secara terpadu.

Banyak aspek yang turut serta menentukan berhasil tidaknya pelaksanaan implementasi Peraturan Daerah Nomor 6Tahun 2014 Tentang Desa yang salah satunya mengatur 
pembangunan yang ada di masyarakat. Tingkat pengetahuan masyarakat dalam memahami peraturan tersebut sudah mulai tumbuh. Guna mengoptimalkan capaian sasaran dan mengantisipasi perubahan yang akan terjadi pada masa yang akan datang, pemerintahan desa Jaya Mentari akan menempuh langkah-langkah sebagai berikut dalam mensosialisasikan pendidikan: 1) Secara bertahap akan melakukan pembinaan kepada masyarakat Jaya Mentari secara berkesinambungan, 2) Meningkatkan pembinaan kepada masyarakat untuk mengerti makna peraturan dan melakukan pengawasan dilapangan secara terus menerus dengan pendekatan yang tepat untuk pengembangan pendidikan. 3) Meningkatkan sosialisasi kepada masyarakat secara bertahap sehingga pengetahuan dan kesadaran masyarakat terhadap pendidikan semakin tumbuh dan semakin tinggi tingkat kesadaran bersekolah. 4) Meningkatkan koordinasi dengan berbagai pihak Dinas Pendidikan, baik di tingkat Kecamatan maupun Kabupaten. 5) Mengupayakan peningkatan sumberdaya aparatur secara bertahap dan memperhatikan skala prioritas.

Ada empat strategi komunikasi pembangunan pendidikan yang telah digunakan oleh pemerintah Kabupaten Sintang khususnya Cabang Dinas Pendidikan selama ini dalam mengkomunikasi kepada masyarakat Desa Jaya Mentari, yaitu: (1) Strategi-strategi yang didasarkan pada media yang dipakai, (2) Strategi-strategi disain instruksional, (3) Strategi-strategi partisipatori, (4) Strategi-strategi pemasaran. Masing-masing strategi mencerminkan suatu rangkaian prioritas tertentu mengenai bagaimana menggunakan komunikasi untuk mencapai kebutuhan-kebutuhan pembangunan.

Ada tiga (3) argumen yang mendasari pendapat itu. Pertama; berkembangnya kesan dalam masyarakat, bahwa pembangunan pendidikan yang disampaikan kepada masyarakat seolah-olah lebih bersifat memberatkan masyarakat karena selalu mengeluarkan beaya yang besar. Kedua; kegiatansosialisasi yang telahdilaksanakanselamainimasihbelum optimal membuat masyarakat memahami arti penting pembangunan pendidikan. Ketiga; secara riil di lapangan diperoleh bukti bahwa sebagian besar masyarakat masih belum paham berkenaan dengan pentingnya pendidikan untuk masa depan masyarakat.

Materi yang disampaikan dalam penyuluhan / sosialisasi antara lain: Obyek pembangunan pendidikan, tata cara peningkatan dan pengembangan pendidikan. Media yang digunakan antara lain melalui tulisan, kejadian gambar-gambar, dan brosur. Hanya saja, sebagian besar masyarakat yang diwawancarai menyatakan penyuluhan / sosialisasi mengenai pembangunan pendidikan jarang dilakukan oleh desa dan lebih banyak dilakukan oleh pemerintah kecamatan dan kabupaten Sintang dalam rangka kunjungan kerja daerah. Minimnya tingkat pemahaman masyarakat terhadap makna pendidikan menyebabkan pengetahuan yang diperoleh juga sedikit. Rendahnya frekuensi sosialisasi tersebut menyebabkan banyak masyarakat yang belum paham dan bahkan binggung tentang hal-hal yang berkenaan dengan pembangunan pendidikan.

Berbagai kegiatan dilakukan pemerintah Desa Jaya Mentari terutama dalam meningkatkan pemahaman dalam pembangunan pendidikan salah satunya adalah melalui pembinaan sebagai upaya mewujudkan sasaran pembangunan pendidikan masyarakat tersebut. Kesejahteraan masyarakat yang diharapkan dapat memberi perubahan pada peningkatan pendidikan dan pengetahuan masyarakat dan khususnya dalam menyekolahkan anaknya. Upaya pembinaan masyarakat dalam pembangunan pendidikan tidak hanya diperankan oleh pemerintahan desa saja, tetapi peran pihak kecamatan dan kabupaten juga sangat diharapkan. Pembinaan terhadap masyarakat desa masih sangat tergantung pada campur tangan pemerintah Kecamatan dan Kabupaten Sintang baik dari Dinas Pendidikan maupun dari Cabang Dinas Pendidikan di Kecamatan Tempunak. Peran Kepala Desa selama ini sudah dirasakan maksimal, dimana hasil-hasil aspirasi masyarakat yang ditampung oleh pemerintah desa dimana Desa Jaya Mentari telah berhasil membangunan 2 (dua) lokal gedung untuk membantu anak-anak di Desa Jaya Mentari yang mau bersekolah dengan pola jarak jauh. Kelemahan yang ditemui sebelum adanya pembangunan pendidikan yang belum dikelola dengan baik. Masyarakat harus bersekolah dengan menempuh jarak yang berkisar belasan kelometer.

Hadirnya Program pemerintah dalam menuntaskan wajib belajar 9 (sembilan) tahun pada prinsipnya dapat diterima dengan baik oleh masyarakat karena berbagai persepsi dan asumsi yang berbeda terhadap kehadiran program pendidikan ini dimana keterbatasan pengetahuan masyarakat dalam memahami dan melaksanakan program pendidikan wajib sembilan tahun tersebut. Setelah berjalan beberapa waktu, menunjukkan pola kerja sama yang menguntungkan masyarakat khususnya anak-anak mereka maka sebagian besar masyarakat menyambut baik niat pemerintah dalam menggalakan pembangunan pendidikan masyarakat sehingga pemerintah Desa Jaya Mentari sering mengundang pihak kabupaten 
memberian penyusluhan dan pembinaan pada masyarakat.

Koordinasidan pelaksanaan pendidikan antara pemerintah desa dengan masyarakat dilaksanakan melalui kebijakan, prosedur dan tata kerja yang disusun bersama maupun melalui perencanaan bersama. Hubungan kerja dalam rangka memajukan pendidikan masyarakat di Desa Jaya Mentari tersebut umumnya dilakukan melalui rapat. Rapat-rapat tersebut untuk menyatukan bahasa dan saling pengertian mengenai sesuatu masalah pembangunan pendidikan yang akan dibahas dan akan memberikan pengarahan, memperjelas atau menegaskan suatu kebijaksanaan yang akan dilaksanakan.

Pola koordinasi antara pemerintah desa dan masyarakat Desa Jaya Mentari dilakukan melalui pembentukan tim atau panitia yang bersifat missal seperti pelaksanaan musyawarah membangun local sekolah yang bersifat swadaya dari masyarakat dan sebagainya. Petugas pelaksana pembinan pembangunan pendidikan berasal dari beberapa unit yang berbeda dalam organisasi seperti Dinas Pendidikan Kabupaten, pengawas dari Cabang Dinas Pendidikan Kecamatan dan pemerintah daerah. Situasi semacam ini menuntut untuk pandai-pandai melakukan koordinasi, sehinggasecarakeseluruhan proses pelayanan selalu berjalan tertib dan lancar.

Teknik koodinasi bidang pendidikan kepada masyarakat sangat beraneka ragam tergantung dari dinas apa yang berkunjung ke Desa Jaya Mentari. Teknik ini dapat berupa presentasi, seminar, lokakarya, sarasehan, dan lain semacaamnya. Dalam melakukan tatap muka ada beberapa hal yang paling penting yang harus di perhatikan pertama. Rancangan proses pelayanan perlu dikemas secara khusus sesuai dengan kebutuhan para pihak yang di hadapi. Kedua, sikap aprisiasif terhadap stakeholders dimana cenderung menggunakan tatap muka dan menyatakan kritik dan aspirasinya. Ketiga, nyatakan dengan tegas dan jelas peran dan fungsi para pihak dalam pengembangan pelayanan.

Kerjasama selama ini yang dilakukan oleh Kepala Desa Jaya Mentari diakui belum optimal, hal ini dilihat dari salah satu bentuk kegiatan seperti penyusunan rencana pembangunan pendidikan masyarakat pada setiap tahun anggaran selalu di ajukan masing-masing oleh tiap-tiap bagian yang ditangani langsung kebagian kaur pemerintahan dengan dimusyawarahkan secara bersama di Kabupaten Sintang melalui Cabang Dinas Pendidikan. Kaur Pemerintahan Desa menyatakan tim dibentuk cenderung hanya untuk pengesahan secara hokum dalam bentuk keputusan Kepala Desa untuk kepentingan penanggungjawaban.
Koordinasi antara bawahan dengan pijabat pemerintah yang menangani pembangunan pendidikan masih sangat rendah. Selama ini terjadi banyaknya lompatan koordinasi sehingga mengabaikan penjenjangan karena beberapa permasalahan harus segera dikomunikasikan dengan pimpinan, sementara pimpinan secara berjenjang cenderung tidak ada ditempat atau kalaupun ada sering terjadi keterlambatan dalam pengambilan keputusan. Sulitnya koordinasi dilaksanakan antara masyarakat dengan Kepala Desa karena kurang harmonisnya hubungan kerja. Masyarakat cenderung mengharapkan perhatian dari Kepala Desa, namun disisi lain Kepala Desa cenderung mengedepankan pelayanan yang lebih baik pada pimpinan tertinggi. Sebagian besar bawahan kurang harmonis pada Kepala Desa karena perhatian dan kepedulian serta penghargaan Kepala Desa kepada masyarakat belum dirasakan oleh masyarakat. Koordinasi kerja di pemerintahan desa sudah tergambar dalam penjenjangan tugas dan fungsi pemerintahan desa yang ada. Jabatan tertinggi di desa adalah Kepala Desa. Kegiatan administrasi dapat berjalan dengan baik dan terhindar dari tumpang tindih tugas apabila koordinasi berjalan dengan baik. Hakikat dari koordinasi adalah perwujudan dari pada kerjasama, saling bantu membantu dan menghargai / menghayati tugas dan fungsi serta tanggungjawab masing-masing.

Membangun hubungan yang harmonis melalui kepedulian dan penghargaan satu dengan yang lainnya merupakan upaya menumbuhkan kembali koordinasi yang baik. Kepala Desa dalam melakukan koordinasi secara efektif, apabila mampu memenuhi beberapa persyaratan koordinasi yang baik, antara lain: hubungan langsung, Kesempatan awal, kontinitas, dinamis, tujuan yang jelas, organisasi yang sederhana, perumusan wewenang dan tanggungjawab yang jelas, komunikasi yang efektif dan kepemimpinan yang efektif. Koordinasi yang efektif ini harus berjalan secara sinergis baik oleh Kepala Dusun, Kaur Pemerintahan desa, dan Kepala Desa. Koordinasi dapat dilakukan dengan berbagai cara, antara lain: Mengadakan pertemuan informal antara para pejabat, rapat, edaran, penyebaran kartu, mengangkat koordinator, buku pedoman kerja, berhubungan dengan alat, membuat symbol ataut anda, dan kode. Cara koordinasi yang tepat dilakukan perangkat desa adalah rapat, pertemuan informal dan pedoman kerja organisasi. Rapat internal instansi tudak hanya dilakukan pada awal pelaksanaan tugas, namun harus rutin dilakukan guna menyelaraskan kegiatan dengan tujuan akhir serta sebagai bentuk membina hubungan kerja antar bawahan dengan pimpinan. 


\section{KESIMPULAN DAN SARAN}

Peran Kepala Desa dalam pembangunan pendidikan di antaranya berperan aktif dalam mensosialisasikan dan mengkoordinasikan pembangunan pendidikan. Selain itu masyarakat juga ikut dibina sehingga mengerti makna dilaksanakannya pembangunan pendidikan bagi masyarakat desa. Faktor-faktor yang mempengaruhi peran komunikasi Kepala Desa dalam pembangunan pendidikan adalah sumber daya manusia yang dianggap masih rendah, karena keterbatasan pengetahuan masyarakat tentang arti dari pembangunan pendidikan itu sendiri. Sarana komunikasi, perilaku masyarakat dan kondisi geografis merupakan bagian yang turut mempengaruhi peran Kepala Desa Jaya Mentari dalam pembangunan pendidikan. Peran komunikasi Kepala Desa dalam pembangunan pendidikan harus direncanakan lebih dahulu dengan melibatkan unsur masyarakat dalam bentuk sosialisasi, pembinaan dan koordinasi yang berkesinambungan. Suatu perencanaan yang terarah menyebabkan kegiatan dapat dilakukan dengan baik dan lancar. Sedangkan pembangunan yang akan dilaksanakan itu harus sesuai dengan kepentingan masyarakat secara keseluruhan, supaya masyarakat akan selalu mau berpartisipasi dalam kegiatan pembangunan.Faktor-faktor yang mempengaruhi peran komunikasi Kepala Desa dalam mendukung program pembangunan pendidikan seperti sumber daya manusia, sarana komunikasi, perilaku masyarakat dan kondisi geografis haruslah menjadi bahan perhatian yang serius. Kemampuan masyarakat harus di tingkatkan lagi, karena potensi alam yang ada sudah menunggu untuk di olah masyarakat sendiri dengan syarat pendidikan harus menunjang. Faktor yang paling utama adalah meningkatkan tingkat pemahaman masyarakat akan pentingnya pengetahuan dalam membangun. Pemerintahan Desa tidak akan berjalan tanpa dukungan penuh dari masyarakat setempat .

\section{DAFTAR PUSTAKA}

Arikunto, 1998. Prosedur Penelitian Suatu Pendekatan Praktis. Jakarta: RinikaCipta.

Ashari, 2003. Sarana dan Prasarana pendukung pembangunan. Jakarta: PT. Rajawali. Dirdjososisworo, 1985. Sosialisasi Dalam Pembangunan. Jakarta: PT. Haji Mas Agung

Effendy, 2005. Efektifitas Komunikasi Dalam Organisasi. Bandung: Ganesa

Faisal, 2005. Penelitian Kualitatif. Malang: Yayasan AsihAsahAsuh
Gie, 2000. Manajemen Personalia dan Pengembangannya. Yogyagkarta BPFE

Hasibuan, 2008. Pengembangan Sumber Daya Manusia. Jakarta: PT. Rajawali

Hedebro, 2004. Peran Komunikasi Dalam Pembangunan Pendidikan. Semarang: PT. Aneka Jaya

Hidayat, 1993. Pembinaan dan Pengembangan Sumber Daya Manusia. Jakarta: Granit

Hovland, 2004. Komunikasi dalam Pembangunan. Jakarta: Fokusmedia

Kadarno, 2001. Koordinasi Dalam Pembangunan. Jakarta: RenikaCipta. Kamus Besar Bahasa Indonesia, 1993. Istilah Pembinaan

Koeswadoyo, 1995. Pembinaan Masyarakat dan Pengelolaannya. Jakarta: PT.Rajawali

Koentjaraningrat, 1985. MetodePenelitian Sosial Masyarakat, PT. Gramedia Pustaka Utama.

Ma'moeri, 2005. MembangunKoordinasi dan Komunikasi Dalam Organisasi. Jakarta: Granit

Mangunhadjana, 1986. Pembinaan Potensi dan Sumber Daya Manusia Bagi Daerah. Jakarta: PT. GramediaPustaka U

Martoyo, 2000. Sistem Informasi dan Komunikasi kepegawaian. Bogor: Cipta Mandala

Mulyadi. 1989. Proses Komunikasi Dalam Organisasi. Jakarta: Granit

Munijaya. 1999. Manajemen Sumber Daya Manusia. Jakarta: Gramedia

Nasution, 1985. Komunikasi Pembangunan dan Implementasinya. Bandung: Gramedia

Presman, 1997. Pembangunan Yang Berkelanjutan. Yogyakrta: Gajah mada

Soemitro, 1993. Langkah-Langkah Pembinaan Yang Berhasil. Yogyakarta: Gajah Mada

Soedjadi, 1990. Sumber Daya Manusia dan Pengelolaannya.Yoyagkarta: Gajah mada 
Singaribun, 1989. Metode Penelitian Survey. Jakarta: BPFE

Suganda, 1991. Prinsip-Prinsip Koordinasi Vertikal dan Horizontal. Semarang: CiptaKarya Utama

Supono, 2001. Pelaksanaan Koordinasi Yang Efektif Bagi Aparatur. Jakarta: Granit

Supriyono, 2000. Anggaran dan Pengelolaannya Bagi Organisasi Secara tepat. Aneka Cipta Lestari. Undang-UndangNomor 20 Tahun 2003 Tentang Sistem Pendidikan Nasional

Wilbur.S. 1976.Komunikasi Dalam Pembangunan. Jakarta: Fokusmedia

Winarno, 2002. Manajemen Pemberdayan Masyarakat. Bandung: Gramedia. 